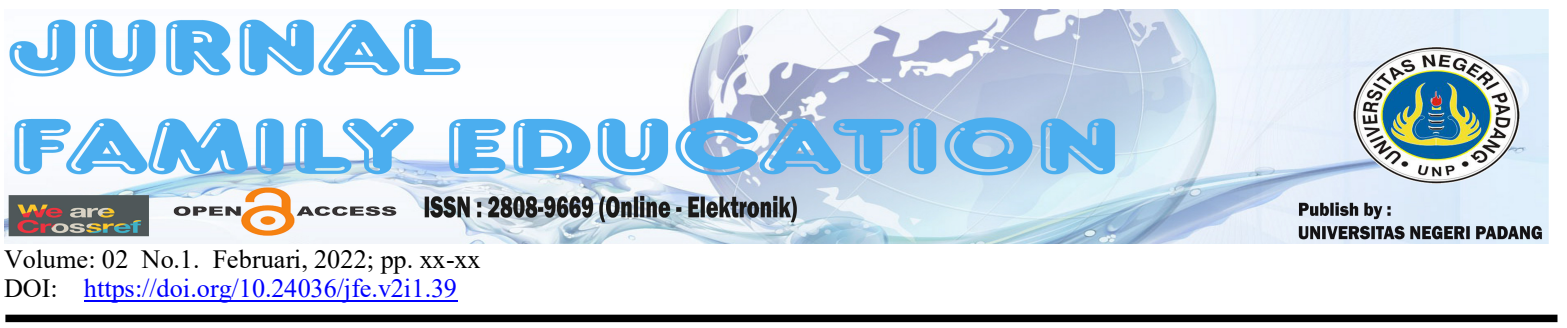

\title{
Hubungan Antara Perhatian Orang Tua Menurut Peserta Didik Dengan Minat Belajar Peserta Pada Pembelajaran Alquran Di TPQ
}

\author{
Utari Handayani, Wirdatul 'Aini \\ Universitas Negeri Padang \\ * e-mail: utarih659@gmail.com
}

\begin{abstract}
This research was motivated by the low interest in learning of students in learning the Koran at TPQ Mushola Nurul Ikhlas Bukik Kaciak Kampung Benteng Nagari Duku. The low interest in learning is thought to be caused by the low attention of parents according to students. The research aims to describe students' interest in learning, describe parental attention according to students, and see the relationship between parental attention according to students and participants' learning interest in learning the Koran at TPQ at Nurul Ikhlas Bukik Kaciak Mosque. This type of research is quantitative research with correlational type. The population in this study were TPQ participants in learning the Koran and the sample was taken by random sampling technique. Data collection techniques in the form of closed interviews and data collection tools in the form of questionnaires.The data analysis technique used the percentage formula and Spearman rho correlation. The results showed that parental attention according to students was categorized as low, students' interest in learning the Koran at TPQ Mushola Nurul Ikhlas Bukik Kaciak was categorized as low, and there was a significant relationship between parental attention according to students and students' interest in learning the Koran. at the TPQ at the Nurul Ikhlas Bukik Kaciak Mosque, Kampung Benteng Nagari Duku, Koto XI Tarusan District, Pesisir Selatan Regency. It is recommended that TPQ managers and educators at the Nurul Ikhlas Bukik Kaciak Kampung Benteng Mosque in order to increase student interest in learning, then can improve things that are deemed necessary to improve learning.
\end{abstract}

Keywords: parental attention, interest in learning, $T P Q$

\section{PENDAHULUAN}

Pendidikan merupakan kebutuhan dasar bagi manusia supaya dapat menambah kualitas hidup dalam memenuhi kebutuhan hidup agar tercapainya kualitas hidup yang semakin maju. Pendidikan merupakan suatu upaya yang mewujudkan generasi yang berilmu pengetahuan, cerdas dalam berfikir, dan bersikap dalam bertindak. Pendidikan merupakan bentuk usaha sadar dan terencana supaya memberikan suasana belajar aktif dan proses pembelajaran berjalan dengan lancar, agar peserta didik dapat mengembangkan potensi diri dan memiliki kekuatan spiritual dalam bidang keagamaan, kecerdasan, berakhlak, dan terampil yang dibutuhkan oleh diri individu, 
bangsa, dan negara (Siska, Solfema, Aini, 2018). Menurut UU No. 20 tahun 2003, menyatakan pendidikan di Indonesia terbagi menjadi tiga jalur yaitu pendidikan formal, informal dan nonformal. Pendidikan nonformal disebut Pendidikan Luar Sekolah merupakan pendidikan masyarakat bertujuan untuk membantu memecahkan masalah terlantarnya pendidikan, baik yang belum sekolah ataupun yang gagal sekolah (Sudjana, 2015).

Pendidikan nonformal memiliki berbagai macam jenjang pendidikan salah satunya yaitu pada pendidikan anak-anak. Dari sejak dini anak-anak harus mendapatkan pendidikan, karena pendidikan merupakan hal utama yang harus di dapatkan anak-anak dari kecil sampai batas umur yang tidak ditentukan. Untuk menciptakan masyarakat yang berpendidikan religius dan harmonis, kelompok pengajian Al Quran berperan aktif melaksanakan pendidikan luar sekolah yang melengkapi serta mengganti fungsi pendidikan formal (Apriani, Tasia \& Sunarti, 2020). Salah satu pendidikan agama yang diperoleh dalam masyarakat yaitu taman pendidikan alquran. Taman pendidikan alquran yaitu bentuk lembaga pendidikan luar sekolah diluar jalur persekolahan yang ditemukan didalam masyarakat. Seperti yang dinyatakan dalam UU Sisdiknas No 20 tahun 2003 ayat 4 menyebutkan bahwa satuan pendidikan nonformal meliputi lembaga pelatihan, kursus, kelompok belajar, PKBM, majelis taklim, taman pendidikan alquran, dan satuan pendidikan sejenis lainnya (Agustina \& Solfema, 2018).

Taman Pendidikan Quran (TPQ) merupakan bagian dari lembaga pendidikan nonformalyang bertujuan untuk membimbing, membina dan mengembangkan potensi yang dimiliki oleh peserta dan menanamkan nilai agama berdasarkan ajaran alquran (Suharyani, 2016). Materi yang di ajarkan cukup bervariasi seperti ilmu alquran, hadist, akidah, akhlak, serta ilmu yang bermanfaat buntuk peserta.Taman pendidikan al quran membantu peserta didik usia 5- 15 tahun dalam mempelajari, memahami, dan memaknai ayat Alquran dan membentuk karakter berdasarkan dengan nilai-nilai Islam. Dalam proses pembelajaran tidak hanya memfokuskan pada al quran saja akan tetapi juga mengutamakan materi pembelajaran yang bervariasi, misalnya belajar membaca iqra untuk anak tingkat awal, bacaan sholat, praktek sholat, ayat pendek, namanama nabi, malaikat dan doa doa harian.

Pendidikan nonformal seperti Taman Pendidikan Alquran (TPQ) begitu banyak tersebar di Kabapaten Pesisir Selatan khususnya Kecamatan Koto XI Tarusan. Hampir semua di kampungkampung terdapat lembaga TPQ. Salah satunya di Mushola Nurul Ikhlas yang terletak di Bukik Kaciak Nagari Duku Kecamatan Koto XI Tarusan merupakan bagian lembaga Pendidikan NonFormal yang ada di kampung ini. TPQ ini memiliki santri yaitu dengan kelompok Iqra' 1 sampai 3 berjumlah 15 orang, kelompok iqra' 4 sampai 6 berjumlah 25 orang, kelompok alquran berjumlah 25 orang. Peserta dengan rentang usia 5-15 tahun tingkat pendidikan SD dan SMP yang tinggal di Kampung Benteng. Pembelajaran dimulai dari jam 3 sore sampai jam 8 malam. Pembelajaran dilaksanakan pada hari sabtu sampai hari kamis, kemudian setiap hari minggu melaksanakan didikan subuh. Tpq ini memiliki 4 tenaga pendidik.

pembelajaran agama khususnya alquran beserta kandungannya dimana alquran merupakan sumber utama yang di ajarkan dalam agama islam, dan dijadikan pedoman hidup. Setiap muslim yang mengetahui isi kandungannya akan bertambah kecintaan untuk membacanya, mempelajarinya, mengamalkan dan menyampaikannya.

Pengetahuan dan kemampuan manusia akan meningkat apabila memperoleh proses belajar, membaca alquran tidak hanya pada tulisan, namun melibatkan berbagai aktivitas visual, berfikir, psikolinguistik dan metakognitif (Gustria \& Wisroni, 2020). Tata cara dan adab dalam membaca alquran seperti adanya pemahamam pada bacaan tajwid, pengucapan makhrijul huruf 
dan makna ayat dalam alquran, oleh sebab itu banyak yang kesulitan dalam membaca alquran. Ini disebabkan karena masih ada yang belum mempelajari alquran dengan benar.

Menyadari betapa pentingnya perhatian orang tua untuk anak, agar dapat meningkatkan minat dan semangat mengikuti pembelajaran. Menurut pendapat Slameto (2013), minat merupakan kecendrungan untuk memperhatikan kegiatan, minat berpengaruh pada pembelajaran, apabila pembelajar yang diberikan tidak sesuai dengan minat maka anak tidak serius mengikuti pembelajaran. Minat belajar merupakan suatu kesukaan ataupun ketertarikan terhadap pembelajaran. Minat merupakan suatu hal yang begitu penting dalam meningkatkan aktifitas belajar, apabila minat belajar cukup tinggi maka kegiatan pembelajaran dilakukan sesuai yang diharapkan begitupun sebaliknya (Febri \& Aini, 2020)

Minat belajar dipengaruhi oleh beberapa faktor, Menurut Iswara (2011), berpendapat bahwa terdapat beberapa faktor yang mempengaruhi minat belajar ialah perhatian orang tua, motivasi belajar, teman, cita-cita, lingkungan, pergaulan fasilitas dan bakat. Ini dapat dijelaskan perhatian orang tua sangat penting untuk dapat mempengaruhi minat belajar. Orang tua berperan penting, aktif untuk meningkatkan minat belajar karena anak yang tinggal dilingkungan keluarga yang peduli akan pendidikan dan peduli pada aktivitas belajar, anak akan cenderung memiliki minat belajar yang tinggi. Perhatian dari orang tua sangat penting untuk memotivasi semangat belajar anak, karena dalam keluarga anak mendapatkan pendidikan dasar dan perhatian yang dapat meningkatkan minat belajar anak. (Wenisa \& Syuraini, 2020).

Dalam keluarga anak akan mendapatkan bimbingan dan perhatian guna untuk membentuk karakter dan wataknya. Anak akan mendapatkan dasar-dasar pendidikan melalui orang tuanya, oleh karena itu orang tua diharuskan bias menanamkan segenap nilai dan norma yang diberlakukan kepada anak supaya anak bisa terarah secara baik (Ismaniar, jamaris \& wisroni, 2018). Demikian apabila perhatian orang tua terhadap anak dapat dimaksimalkan supaya dapat meningkatkan minat belajar anak (Nopaldi \& Setiawati, 2018). Inilah yang menjadi alasan peneliti memilih perhatian orang tua sebagai hal yang bisa mempengaruhi minat belajar anak sesuai dengan kondisi saat ini.

Berdasarkan observasi penulis yang dilakukan selama Kuliah Kerja Lapangan berlangsung. Salah satu program KKL yang penulis ambil ialah mengajarkan Quran kepada peserta didik di TPQ Mushola Nurul Ikhlas. Penulis menemui terdapat masalah yang menunjukan kurang berhasilnya peserta dalam pembelajaran alquran dikarenakan rendahnya minat belajar kemudian perhatian dari orang tua.

Penulis mengamati pada saat pembalajaran yaitu pada saat proses pembelajaran alquran berlangsung terlihat partisipasi peserta misalnya masih ada peserta yang sering tidak hadir saat pembelajaran, datang terlambat, konsentrasi peserta yang masih rendah, misalnya peserta masih ada yang tidak memperhatikan pembelajaran, berbicara sesama teman saat pembelajaran berlangsung, kemudian keaktifan peserta yang masih rendah, terlihat dari peserta yang kurang aktif saat pembelajaran saat bertanya dan menjawab pertanyaan. Berikut data tabel minat belajar dapat dilihat pada tabel 2 .

Tabel 2. Data Minat Belajar Peserta pada pembelajaran alquran TPQ Musholla Nurul Ikhlas Bukik Kaciak Tahun 2021

\begin{tabular}{|c|c|c|c|c|c|c|c|}
\hline \multirow[b]{2}{*}{ No. } & \multirow[b]{2}{*}{ Tanggal } & \multirow{2}{*}{$\begin{array}{l}\text { Jumlah } \\
\text { peserta }\end{array}$} & \multirow[b]{2}{*}{ Hadir } & \multicolumn{4}{|c|}{ Aspek yang diamati } \\
\hline & & & & $\begin{array}{l}\text { Bertany } \\
\text { a }\end{array}$ & $\begin{array}{l}\text { Menjawab } \\
\text { pertanyaan }\end{array}$ & $\begin{array}{l}\text { Mencatat } \\
\text { pembelajara }\end{array}$ & $\begin{array}{l}\text { Mengulang } \\
\text { pembelajara }\end{array}$ \\
\hline
\end{tabular}

Jurnal Family Education

Open Access Journal 


\begin{tabular}{|c|c|c|c|c|c|c|c|}
\hline & & & & & & $\mathbf{n}$ & $\mathbf{n}$ \\
\hline 1. & $25 / 10 / 2021$ & 25 & 14 & 3 & 4 & 3 & 8 \\
\hline 2. & $26 / 10 / 2021$ & 25 & 17 & 3 & 3 & 7 & 14 \\
\hline 3. & $27 / 10 / 2021$ & 25 & 9 & 6 & 4 & 5 & 7 \\
\hline 4. & $28 / 10 / 2021$ & 25 & 11 & 4 & 2 & 8 & 9 \\
\hline 5. & $30 / 10 / 2021$ & 25 & 19 & 8 & 6 & 6 & 14 \\
\hline
\end{tabular}

Sumber : Hasil observasi di Mushola Nurul Ikhlas Bukik Kaciak Kampung Benteng Nagari Duku

Berdasarkan data yang penulis diperoleh dari minat belajar peserta pada pembelajaran alquran di TPQ terlihat masih banyak peserta didik yang minat belajarnya tergolong masih rendah, terlihat dari beberapa aspek yang diamati, seperti kehadiran peserta, partisipasi peserta, keaktifan peserta dan kemudian konsentrasi peserta terhadap pembelajaran alquran. Artinya minat belajar peserta dalam pembelajaran alquran di TPQ Mushola Nurul Ikhlas tergolong masih rendah. Berdasarkan hasil observasi terdapat factor yang mempengaruhi minat belajar peserta salah satunya perhatian orang tua.

Berdasarkan hasil wawancara bersama guru TPQ ditemukan bahwa peserta kurang antusias mengikuti pembelajaran. Peserta ada yang berbicara disaat pembelajaran berlangsung, tidak memperhatikan guru, mengganggu temannya, ada peserta yang junuh karena metode pembelajaran tiap minggunya, tidak ada motivasi baru, terkadang ada peserta yang tidak mengikuti pembelajaran. Dari wawancara dengan peserta, ada sebagian dari orang tua mereka yang kurang memperhatikan kegiatan belajarnya, guru mengatakan bahwa tidak banyak orang tua memperhatikan kegiatan belajar dan beberapa yang menanyakan perkembangan anaknya. Oleh karena itu supaya anak berminat mengikuti pembelajaran, maka orang tua harus memberikan perhatian terhadap anaknya, hal ini dilakukan supaya anak mendapatkan hasil belajar yang maksimal dari orang tuanya sendiri (Maulani \& Bartin, 2021).

Berdasarkan permasalahan tersebut, penulis tertarik mengambil judul skripsi yaitu"Hubungan Perhatian Orang Tua Menurut Peserta dengan Minat Belajar Peserta pada Pembelajaran Alquran Di TPQ Mushola Nurul Ikhlas Bukik Kaciak Kampung Benteng Nagari Duku Kecamatan Koto XI Tarusan Kabupaten Pesisir Selatan”.

\section{METODE PENELITIAN}

Jenis penelitian ini adalah penelitian kuantitatif jenis korelasional, penelitian ini bertujuan untuk melihat hubungan suatu variabel. Sugiyono (2018), mengemukakan bahwa penelitian kuantitatif dengan jenis korelasi yaitu penelitian untuk mengukur hubungan antara dua variable.. Populasi pada penelitian ini yaitu peserta TPQ yang kelompok alquran berjumlah 25 orang. Sampel diambil dari jumlah populasi. Teknik pengambilan sampel mengunakan tekni simple random sampling. Populasi berjumlah 25 orang dan di jadikan sampel sebanyak $80 \%$ dari populasi, jadi sampel pada penelitian ini berjumlah 20 orang. Teknik pengumpulan data yaitu dengan wawancara tertutup dan alat pengumpulan data menggunakan angket. Untuk teknik analisis yaitu:

1. Gambaran perhatian orang tua menurut peserta didik dengan minat belajar peserta dihitung dengan rumus persentase yang dikemukakan oleh (Arikunto, 2014). 


$$
\mathrm{P}=\frac{F}{W} \times 100 \%
$$

keterangan :

$\mathrm{P}=$ Persentasi hasil yang diperoleh

$\mathrm{F}=$ Frekuensi jawaban masing-masing pertanyaan

$\mathrm{N}=$ Jumlah responden.

2. Hubungan antara perhatian orang tua menurut peserta didik dengan minat belajar peserta didik menggunakan rumus Sparman Rho yang dikemukakan oleh (Arikunto, 2014).

$$
\begin{aligned}
& \text { rho }=1 \frac{6 \sum d^{2}}{N\left(N^{2}-1\right)} \\
& \text { keterangan: } \\
& \text { Rho }=\text { koefisien } \\
& \mathrm{N} \quad=\text { sampel } \\
& \mathrm{d} \quad=\text { selisih antara dua subjek }
\end{aligned}
$$

\section{HASIL PENELITIAN}

\section{Gambaran Perhatian Orang Tua menurut Peserta Didik di Kampung Benteng Nagari Duku Kecamatan Koto XI Tarusan Kabupaten Pesisir Selatan}

Data mengenai perhatian orang tua menurut peserta didik di tpq mushola nurul ikhlas, diungkapkan melalui beberapa subvariabel, yakni: 1) Memberikan kasih sayang terdapat tujuh item pertanyaan; 2) Memberikan bimbingan terdapat lima item pertanyaan; 3) Memfasilitasi anak terdiri dari empat item pertanyaan; dan 4) Menciptakan suasana belajar aman dan nyaman terdiri dari empat item pertanyaan.

keseluruhan variabel berjumlah sebanyak 20 item pertanyaan. Untuk pengolahan data pada setiap item pertanyaan dengan skor (SL) 4, (SR) 3, (JR) 2, (TP) 1. Untuk masing-masing data dikelompokan berdasarkan hitungan presentase dan rata-rata. Untuk lebih jelasnya dapat diamati melalui gambar berikut.

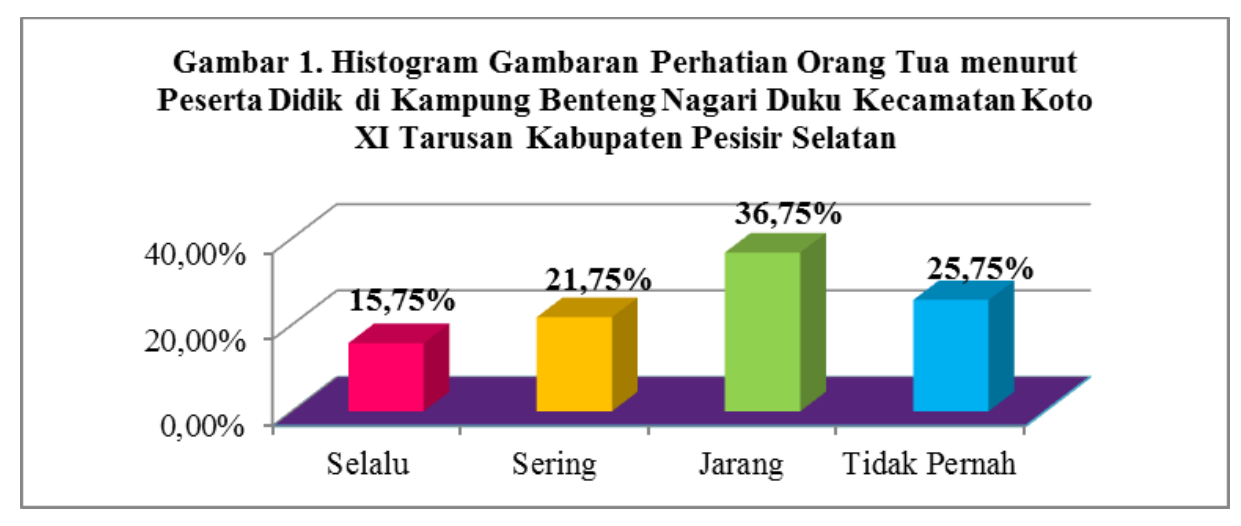

Berdasarkan data tersebut diketahui bahwa perhatian orang tua menurut peserta didik di Kampung Benteng Nagari Duku, responden yang memilih jawaban (SL) sebanyak 15,75\%, yang memilih (SR) sebanyak 21,75\%, yang memilih (JR) sebanyak 36,75\% dan yang memilih jawaban (TP) sebanyak 25,75\%. Dari pengelolaan data tersebut dapat diketahui perhatian orang 
tua menurut peserta didik di tpq musholla nurul ikhlas Kampung Benteng Nagari Duku Kecamatan Koto XI Tarusan Kabupaten Pesisir Selatan.

Gambaran Minat Belajar Peserta Didik pada Pembelajaran Alquran di TPQ Mushola Nurul Ikhlas Bukik Kaciak Kampung Benteng Nagari Duku Kecamatan Koto XI Tarusan Kabupaten Pesisir Selatan

Data mengenai minat belajar peserta didik pada pembelajaran alquran di TPQ Mushola Nurul Ikhlas Bukik Kaciak Kampung Benteng, diungkapkan melalui beberapa subvariabel, yakni: 1) Perasaan senang terhadap objek terdiri dari enam item pertanyaan; 2) Perhatian dan konsentrasi terhadap objek terdiri dari empat item pertanyaan; 3) Ketertarikan terhadap objek terdiri dari lima item pertanyaan; dan 4) Partisipasi aktif terdiri dari lima item pertanyaan.

keseluruhan variabel ini berjumlah sebanyak 20 item pertanyaan. Untuk pengolah data pada item pertanyaan dengan skor (SL) 4, (SR) 3, (JR) 2, (TP) 1. Untuk masing-masing data dikelompokan berdasarkan hitungan presentase dan rata-rata. Untuk lebih jelasnya diamati melalui gambar berikut.

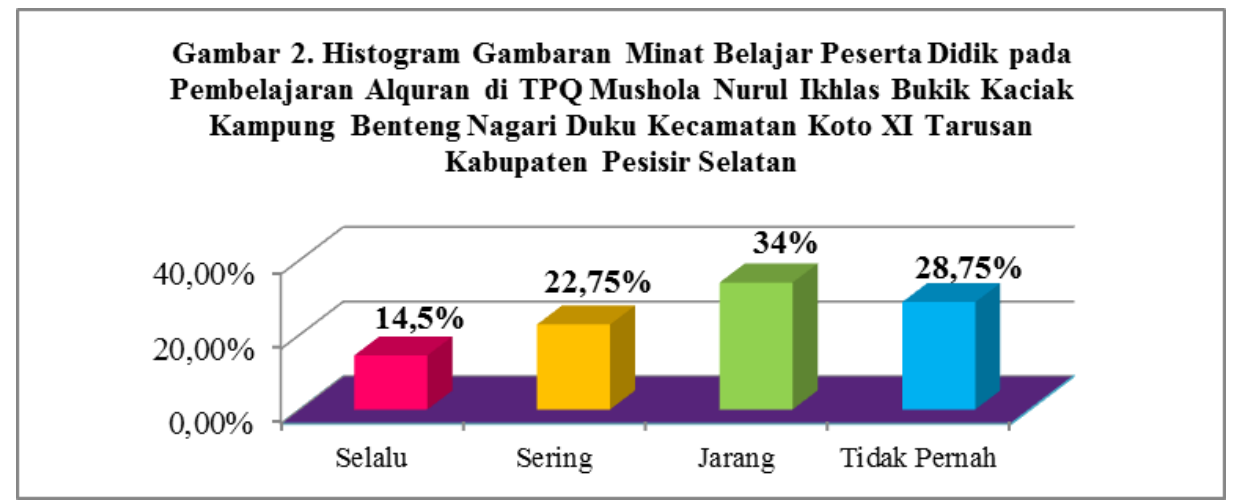

Berdasarkan data tersebut diketahui minat belajar peserta didik pada pembelajaran alquran di TPQ Mushola Nurul Ikhas Bukik Kaciak Kampong Benteng Nagari Duku, untuk responden yang memilih (SL) sebanyak $\mathbf{1 4 , 5 \%}$, untuk yang memilih jawaban (SR) sebanyak $\mathbf{2 2 , 7 5 \%}$, untuk yang memilih (JR) sebanyak $\mathbf{3 4 \%}$ dan untuk yang memilih jawaban (TP) sebanyak $\mathbf{2 8 , 7 5 \%}$. Dari pengelolaan data tersebut diketahui minat belajar peserta didik pada pembelajaran alquran di TPQ Mushola Nurul Ikhlas Bukik Kaciak Kampung Benteng Nagari Duku dikategorikan masih rendah.

Hubungan antara Perhatian Orang Tua Menurut Peserta Didik denan minat belajar Peserta Pada Pembelajaran Alquran Di Tpq Mushola Nurul Ikhlas Bukik Kaciak Kampung Benteng Nagari Duku Kecamatan Koto XI Tarusan Kabupaten Pesisir Selatan

Data mengenai hubungan antara perhatian orang tua menurut peserta didik dengan minat belajar peserta pada pembelajaran alquran di TPQ di Mushola Nurul Ikhlas Bukik Kaciak Kampung Benteng Nagari Duku Kecamatn Koto XI Tarusan Kabupaten Pesisir Selatan, diperoleh data melalui penyebaran angket dilakukukan kepada responden, berikut hasil data berdasarkan uraian tabel 3 berikut.

Tabel 3. Data Hubungan antara Perhatian Orang Tua Menurut Peserta Didik dengan Minat Belajar Peserta pada Pembelajaran Alquran di TPQ di Mushola Nurul Ikhlas 


\begin{tabular}{|c|c|c|c|c|c|c|}
\hline \multirow{2}{*}{ Responden } & \multicolumn{2}{|c|}{ Skor } & \multicolumn{2}{|c|}{ Rank } & \multirow{2}{*}{$\begin{array}{c}\mathbf{D}=\mathbf{R x}- \\
\mathbf{R y}\end{array}$} & \multirow{2}{*}{$\begin{array}{c}\text { D } \\
\text { Kuadrat }\end{array}$} \\
\hline & $\mathbf{X}$ & $\mathbf{Y}$ & $\mathbf{R x}$ & $\mathbf{R y}$ & & \\
\hline 1. & 68 & 70 & 5,5 & 3 & 2,5 & 6,25 \\
\hline 2. & 30 & 31 & 18,5 & 15,5 & 3 & 9 \\
\hline 3. & 34 & 34 & 12 & 10,5 & 1,5 & 2,25 \\
\hline 4. & 68 & 66 & 5,5 & 5,5 & 0 & 0 \\
\hline 5. & 35 & 38 & 11 & 8 & 3 & 9 \\
\hline 6. & 30 & 35 & 18,5 & 9 & 9,5 & 90,25 \\
\hline 7. & 33 & 29 & 13 & 18 & -5 & 25 \\
\hline 8. & 69 & 66 & 3,5 & 5,5 & -2 & 4 \\
\hline 9. & 37 & 29 & 9 & 18 & -9 & 81 \\
\hline 10. & 36 & 27 & 10 & 20 & -10 & 100 \\
\hline 11. & 69 & 29 & 3,5 & 18 & $-14,5$ & 210,25 \\
\hline 12. & 32 & 65 & 14,5 & 7 & 7,5 & 56,25 \\
\hline 13. & 38 & 33 & 8 & 12 & -4 & 16 \\
\hline 14. & 30 & 31 & 18,5 & 15,5 & 3 & 9 \\
\hline 15. & 72 & 68 & 1 & 4 & -3 & 9 \\
\hline 16. & 30 & 32 & 18,5 & 13,5 & 5 & 25 \\
\hline 17. & 31 & 32 & 16 & 13,5 & 2,5 & 6,25 \\
\hline 18. & 71 & 72 & 2 & 1 & 1 & 1 \\
\hline 19. & 32 & 34 & 14,5 & 10,5 & 4 & 16 \\
\hline 20. & 65 & 71 & 7 & 2 & 5 & 25 \\
\hline \multicolumn{6}{|c|}{ Jumlah } & 700,5 \\
\hline
\end{tabular}

Mengacu dari data hubungan antara perhatian orang tua menurut peserta didik dengan minat belajar tersebut, data dapat diolah berdasarkan rumus korelasi rank order berikut:

$$
\begin{aligned}
\text { Rho } & =1-\frac{6 \sum D^{2}}{n\left(n^{3}-1\right)} \\
& =1-\frac{6 \times 700,5}{20\left(20^{2}-1\right)} \\
& =1-\frac{700,5}{20(400-1)} \\
& =1-\frac{700,5}{7980} \\
& =1-0,088 \\
& =0,912
\end{aligned}
$$

Berdasarkan hasil analisis data dengan rumus korelasi rank order, $\mathrm{r}$ hitung $=0,912$ dihubungkan dengan $r$ table $=0,444$ dengan $n=20$, dan setelah diamati $r_{\text {hitung }}>r_{\text {tabel }}$ dengan pengolahan data. Berdasarkan hasil analisis dapat disimpulkan terdapat hubungan yang signifikan antara perhatian orang tua menurut peserta didik dengan minat belajar peserta pada pembelajaran 
alquran di TPQ di Mushola Nurul Ikhlas Bukik Kaciak Kampung Benteng Nagari Duku Kecamatan Koto XI Tarusan Kabupaten Pesisir Selatan. Berdasarkan hasil diatas dapat disimpulkan bahwa semakin tinggi perhatian orang tua maka minat belajar peserta juga semakin tinggi, sebaliknya apabila semakin rendah perhatian orangtua semakin rendah perhatian orang tua maka minat belajar peserta didik juga semakin rendah.

\section{PEMBAHASAN}

\section{Gambaran Perhatian Orang Tua menurut Peserta Didik di Kampung Benteng Nagari Duku Kecamatan Koto XI Tarusan Kabupaten Pesisir Selatan}

Berdasarkan hasil penelitian menunjukan bahwa perhatian orang tua menurut peserta didik di Kampung Benteng dikategorikan masih rendah. Dideskripsikan jumlah item pertanyaan yang disediakan lebih banyak peserta didik menjawab jarang. Orang tua di Kampung Benteng jarang memberikan kasih sayang, jarang memberikan bimbingan, jarang memfasilitasi anak dan jarang menciptakan suasana belajar aman dan nyaman.

Didalam keluarga, anak akan mendapat bimbingan dan perhatian dari orang tuanya guna untuk membentuk karekter dan watak anak. Anak akan mendapatkan dasar-dasar pendidikan dan pengetahuan dan norma-norma tingkah laku orang tua. Oleh sebab itu orang tua harus menanamkan nilai norma kepada anak supaya anak dapat terarah kearah yang lebih baik, Orang tua harus mampu menjalin keharmonisan agar anak kondusif melakukan aktifitas belajar.

Perhatian orang tua terhadap anak memiliki pengaruh yang begitu besar untuk perkembangan anak. Hal ini dikarenakan orangtua merupakan lembaga sosial dan lembaga pendidikan pertama untuk anak. Sehingga orang tua harusnya bijaksana dalam membimbing dan mengarahkan anak supaya kepribadian yang baik akan selalu senantiasa tertanam pada anak, termasuk juga kegiatan belajar anak. Orang tua juga memberikan semangat dan memberikan dorongan agar anak mampu mengembangkan kemampuan yang dimiliki anak (Walgito 2014). Sehingga demikian orangtua tentunya harus memberikan arahan terhadap anaknya supaya anaknya dapat berkembang dengan baik.

Perhatian orang tua merupakan bentuk simpati, kasih sayang serta bentuk peduli orang tua akan keberadaan anak. Selain itu orang tua juga membimbing kegiatan belajar anaknya melalui, penyediaan sarana dan prasarana pembelajaran sebagai pendukung proses pembelajaran bagi anak. Bentuk lain dari kepedulian orang tua terhadap anaknya adalah memberikan fasilitas dan apresiasi pada anak dalam proses belajar (Shaumi \& Ismaniar, 2020).

Menurut Padalingan (2016), keluarga sebagai tempat berlangsungnya pendidikan dapat menimbulkan kemudahan maupun kesulitan bagi anak, adapun faktor yang dimaksud yaitu: pertama cara orangtua dalam mendidik anak. Apabila orang tua terlalu keras dalam mendidik anak maka akan menghilangkan kepercayaan diri anak sehingga anak kesulitan dalam belajar. Kedua kurangnya bimbingan dan perhatian dari orang tua. Sebagai individu yang menuju dewasa tentunya anak memerlukan bimbingan dan perhatian dari orang tua sehingga sikap untuk belajar dapat tertanam dengan baik pada anak. Ketiga kurangnya peralatan belajar yang disediakan orang tua. Fasilitas belajar yang tersedia lengkap akan memudahkan anak untuk belajar dengan baik sebaliknya apabila peralatan yang disediakan kurang, maka anak mengalami kesulitan dalam belajarnya.

Berdasarkan penjelasan tersebut, disimpulkan bahwa perhatian orang tua merupakan sesuatu yang sangat penting untuk meningkatkan minat belajar anak. Orang tua yang memberikan 
perhatian lebih untuk perkembangan belajar anak, akan menjadikan anak mampu berkembang dengan baik, mempunyai minat dalam belajarnya dan memperoleh hasil belajar secara maksimal.

\section{Gambaran Minat Belajar Peserta Didik pada Pembelajaran Alquran di TPQ Mushola Nurul Ikhlas Bukik Kaciak Kampung Benteng Nagari Duku Kecamatan Koto XI Tarusan Kabupaten Pesisir Selatan}

Hasil penelitian ini mejelaskan minat belajar peserta didik pada pembelajaran alquran di TPQ Mushola Nurul Ikhlas Bukik Kaciak Kampung Benteng Nagari Duku dikategorikan masih rendah. dideskripsikan dari jumlah item pertanyaan yang disediakan banyak peserta didik yang menjawab jarang. Peserta didik terlihat kurang senang dalam belajar, kurang memperhatikan dan kurang berkonsentrasi dalam belajar, kurang tertarik dalam belajar dan kurang berpartisipasi selama belajar di TPQ di Mushola Nurul Ikhlas Bukik Kaciak Kampung Benteng Nagari Duku.

Minat belajar merupakan hal yang begitu penting untuk dimiliki oleh seseorang. Sesorang akan merasa tergerak dan termotivasi untuk melakukan sesuatu da melakukan tindakan dengan adanya minat belajar (Yulidar, Syuraini, \& Ismaniar, 2018). Menurut pendapat Crow dalam Djaali, (2014) menyebutkan jika berurusan dengan orang, benda, aktifitas ataupun pengalaman yang dapat memicu kegiatan, maka gaya dorongan tersebut di dorong dengan adanyaminat. Pendapat Soemanto, (2012) minat ada karena senang terhadap sesuatu, minat cenderung memperhatiakan secara terus menerus dan perasaan senang.

Menurut pendapat Slameto (2013) ada beberapa ciri-ciri minat belajar yaitu: (a) dalam memahami pelajaran mempunyai kencendrungan yang tetap, (b) gemar terhadap sesuatu yang diminati, (c) memperoleh rasa puas dan bangga terhadap pencapaian yang diminati, (d) tertarik pada suatu yang digemari, (e) suka padahal yang diamati. Sedangkan menurut pendapat Djamarah (2015), minat peserta didik pada pembelajaran yang diamati melalui tindakan yang ditampilkan, yaitu pada: (1) perhatian lebih pada sesuatu tanpa menghiraukan lainnya, (2) rasa suka dan ketertarikan terhadap sesuatu yang diminati, (3) aktif dalam kegiatan. Minat menjadi sangat penting dalam melakukan proses pembelajaran, apabila peserta memiliki minat belajar tinggi terhadap pembelajaran maka kegiatan belajar dilakukan sesuai dengan yang diharapkan begitupun sebaliknya ( Febri \& Aini, 2020).

Minat merupakan suatu aktivitas yang dapat mendorong untuk melakukan sesuatu hal yang dapat meningkatkan proses belajar mengajar (Nasution, 2014). Hal yang dapat medorong minat beajar peserta didik yaitu dengan kondisi fisik dan psikis peserta didik sehat dan senantiasa mengikuti pembelajaran dengan baik. Minat dapat bermanfaat untuk motivasi supaya dapat meningkatkan prestasi belajar, karena dengan adanya minat belajar maka peserta didik akan konsentrasi mengikiti pembelajaran. Maka hal ini dapat meningkatkan prestasi yang baik dan nilai yang bagus pada peserta didik (Fathurrohman, 2012).

Minat belajar merupakan faktor yang menyebabkan atau mempengaruhi pencapaian hasil belajar (Nopaldi \& Setiawati, 2018). Apabila peserta didik memiliki minat belajar yang tinggi untuk belajar maka pembelajaran yang dilakukan tidak adanya paksaan dan berdasarkan keinginan sendiri begitupun sebaliknya apabila peserta didik memiliki minat belajar yang rendah, peserta didik cenderung lebih pasif sehingga akan berdampak buruk terhadaap hasil belajar peserta didik (Djamarah, 2015).

Berdasarkan penjelasan diatas dapat disimpulkan minat belajar peserta didik pada pembelajaran alquran di TPQ Mushola Nurul Ikhlas Bukik Kaciak Kampung Benteng Nagari Duku tergolong masih rendah. Oleh sebab itu minat belajar peserta didik harus diperhatikan untuk 
melaksanakan kegiatan belajar, jika minat belajar peserta didik tinggi maka peserta didik lebih mudah mendapatkan hasil belajar tang maksimal.

\section{Hubungan antara Perhatian Orang Tua menurut Peserta Didik dengan Minat Belajar Peserta pada Pembelajaran Alquran di TPQ di Mushola Nurul Ikhlas Bukik Kaciak Kampung Benteng Nagari Duku Kecamatan Koto XI Tarusan Kabupaten Pesisir Selatan}

Berdasarkan hasil analisis data dengan menggunakan rumus Korelasi Rank Order didapatkan hasil bahwa $r_{\text {hitung }}>r_{\text {tabel. }}$. Berdasarkan hasil data tersebut dapat disimpulkan bahwa terdapat hubungan siginifikan antara perhatian orang tua menurut peserta didik dengan minat belajar peserta pada pembelajaran alquran di TPQ di Mushola Nurul Ikhlas Bukik Kaciak Kampung Benteng. Maka dengan demikian disimpulkan bahwa semakin tinggi perhatian orang tua maka minat belajar peserta didik juga semakin tinggi, sebaliknya apabila semakin rendah perhatian orang tua maka minat belajar peserta didik juga semakin rendah.

Menurut Slameto (2013), minat belajar peserta didik dipengaruhi oleh berbagai faktor, yakni pertama faktor intern yaitu terdapat dalam diri peserta didik: kondisi kesehatan ataupun cacat tubuh, keinginan, cita-cita, kemampuan untuk melakukan sesuatu, kematangan serta faktor pskologis peserta didik lainnya. Kedua faktor ekstern yaitu faktor dari luar peserta didik seperti: pola asuh orang tua, kondisi ekonomi keluarga, harapan orang tua, perhatian orang tua, teman sebaya, faktor sekolah, media masa dan teman bergaul atau lingkungan masyarakat. Sementara menurut Sesti (2018), terdapat beragam faktor yang bisa mempengaruhi minat belajar yaitu, motivasi belajar, perhatian orang tua, teman cita-cita, lingkungan, pergaulan, fasilitas dan bakat.

Menurut pendapat Slameto (2013) dan Sesti (2018), disimpukan bahwa yang mempengaruhi minat belajar peserta didik yaitu perhatian orang tua. Orang tua yang mengawasi aktivitas belajar anaknya dengan baik akan menjadikan anak terdorong dan semangat dalam belajarnya sehingga anak berminat dalam belajarnya dan serta memberikan kemudahan bagi anak untuk mendapatkan hasil belajar secara maksimal.

Menurut penelitian dilakukan Maulani \& Bartin (2021), menyimpulkan bahwa perhatian orang tua pada pembelajaran anak mampu mempengaruhi minat belajar anak di RW II Kelurahan Parak Gadang Timur. Orang tua memenuhi kebutuhan belajar anak, menyediakan fasilitas belajar, memberikan motivasi belajar, dan memberikan bimbingan belajar secara tidak langsung mendorong anak untuk semangat dan antusias dalam belajar sehingga anak berminat dalam belajarnya dan memudahkan anak untuk mendapat hasil belajar dengan maksimal.

Perhatian dan peranan orang tua tentang pendidikan anaknya dapat membantu keberhasilan pendidikan anaknya, dimana peran orang tua yakni seperti sebagai pendidik (educator), pendorong (motivator), fasilitator dan sebagai pembimbing anak-anaknya. Di dalam keluarga, orang tua wajib memberikan perhatian dan melaksanakan perananya sebagai orang tua. Orang tua mempunyai fungsi tersendiri dalam sebuah keluarga. Menurut Ismaniar (2019), fungsi orangtua adalah: sebagai sosialisasi, sebagai afeksi, edukatif, religious, protektif, dan ekonomis. Orang tua merupakan pendidik paling terdekat dengan anak, dan orang tua lah yang bertanggungjawab atas perkembanagan minat belajar seorang anak, dengan perhatian yang diberikan orang tua dapat mempengaruhi minat belajar anak. Orangtua menjadi kunci keberhasilan bagi anak, khususnya dalah upaya peningkatakan minat belajar dan keberhasilan belajar anak. oleh karenanya peranan orangtua dalam membimbing dan mengarahkan anak dalam meningkatkan hasil belajarnya adalah aktivitas yang sangat penting (Padalingan, 2016). 
Berdasarkan uraian tersebut, dapat disimpulkan adanya hubungan yang siginifikan antara perhatian orang tua menurut peserta didik dengan minat belajar peserta pada pembelajaran alquran di TPQ di Mushola Nurul Ikhlas Bukik Kaciak Kampung Benteng. Semakin tinggi perhatian orangtua maka minat belajar peserta didik juga semakin tinggi, sebaliknya apabila semakin rendah perhatian orang tua maka minat belajar peserta didik juga semakin rendah.

\section{SIMPULAN}

Kesimpulan dari penelitian hubungan antara perhatian orang tua menurut peserta didik dengan minat belajar peserta pada pembelajaran alquran di TPQ di Mushola Nurul Ikhlas Bukik Kaciak Kampung Benteng, yakni: 1) Perhatian orang tua menurut peserta didik di Kampung Benteng Nagari Duku Kecamatan Koto XI Tarusan Kabupaten Pesisir Selatan dikategorikan masih rendah. Dari indikator yang diteliti terlihat bahwa orang tua kurang memberikan kasih sayang, kurang memberikan bimbingan, dan kurang memfasilitasi anak dalam aktivitas belajarnya; 2) minat belajar peserta didik pada pembelajaran alquran di TPQ Mushola Nurul Ikhlas Bukik Kaciak Kampung Benteng Nagari Duku dikategorikan masih rendah. Dari indikator yang diteliti terlihat bahwa peserta didik kurang senang dalam belajar, kurang perhatian dan kurang berkonsentrasi, kurang tertarik dalam belajar dan kurang berpartisipasi dalam belajar; dan 3) Hasil pengelohan data memperlihatkan bahwasanya terdapat hubungan siginifikan antara perhatian orang tua menurut peserta didik dengan minat belajar peserta pada pembelajaran alquran di TPQ di Mushola Nurul Ikhlas Bukik Kaciak Kampung Benteng Nagari Duku Kecamatan Koto XI Tarusan Kabupaten Pesisir Selatan.

\section{SARAN}

Saran dari penulis untuk penelitian ini yaitu: (1) diharapkan kepada pengelola TPQ di Mushola Nurul Ikhlas Bukik Kaciak Kampung Benteng agar dapat meningkatkan minat belajar peserta, dan hal-hal yang dirasa perlu agar dapat menunjang proses pembelajaran; 2) Diharapkan kepada orang tua untuk dapat memperhatikan aktivitas belajar supaya mendapatkan hasil belajar yang maksimal; dan 3) diharapkan untuk peneliti selanjutnya supaya menemukan variable lain yang berpengaruh terhadap minat belajar anak.

\section{REFERENSI}

Agustina \& Solfema. (2018). Gambaran Kedisiplinan Santri Taman Pendidikan Al Quran Di Masjid Al Hidayah Kota Solok. Jurnal Spektrum Pendidikan Luar Sekolah, 6 (4), 394.

Aisyah Andini Febri, W. A. (2020). Hubungan Antara Minat dengan Aktivitas Belajar Waega Belajar Progam Paket C di SPNF 1 Tanah Datar. Ranah Research.

Apriani, Tasia \& Sunarti, V. (2020). Intrinsic Motivation Of Mothers In Following The Al Quran Recitation At Imaduddin Mosque Kampung Lapai Padang City. Jurnal Spektrum Pendidikan Luar Sekolah., 8 (1), 72.

Arikunto, S. (2014). Prosedur Penelitian Suatu Pendekatan Praktik. Jakarta: Rineka Cipta.

Aziz, S. (2015). Pendidikan Keluarga. Yogyakarta: Gava Media.

Djaali. (2008). Psikologi Pendidikan. Jakarta: Bumi Aksara.

Djamarah, S. B. (2015). Psikologi Belajar. Jakarta: Rineka Cipta.

Fathurrohman, M. (2012). Belajar dan Pembelajaran. Yogyakarta: Teras.

Gustria, N., \& Wisroni, W. (2020). Hubungan Antara Pengelolaan Lingkungan Belajar dengan 
Hasil Belajar Peserta Tahfidz di TPQ-TPSQ Al-Hasib Beringin Nagari Lansat Kadap

Kecamatan Rao Selatan Kabupaten Pasaman. SPEKTRUM: Jurnal Pendidikan Luar Sekolah, $8(3)$.

Ismaniar; Jamaris; Wisroni. (2018). Pentingnya Pemahaman Orang Tua tentang Karakteristik Pembelajaran AUD dalam Penerapan Model Environmental Print Berbasis Keluarga untuk Meningkatkan Kemampuan Membaca Awal Anak. KOLOKIUM: Jurnal Pendidikan Luar Sekolah, 6(2), 93-100.

Ismaniar, I. (2019). Optimalisasi Peran Keluarga Dalam Stimulasi Kemampuan Membaca Awal Anak Melalui Pendekatan Environmental Print. E-Tech: Jurnal Ilmiah Teknologi Pendidikan, $6(2), 1-8$.

Iswara, J. W. (2011). Studi Minat Belajar Matematika Pada Siswa Kelas IV Sekolah Dasar Negeri Pepen Kecamatan Wates Kabupaten Kulon Progo. Universitas Negeri Yogyakarta.

Marina Siska, Solfema, wirdatul A. (2018). Hubungan Dukungan Sosial Orang Tua dengan Hasil Belajar Santri di MDA Nurul HAQ Nagari Cubadak Kecamatan Duo Koto Kabupaten Pasaman. Pendidikan Luar Sekolah, 1 Nomor 2.

Maulani, N. H., \& Bartin, T. (2021). Hubungan Antara Perhatian Orang Tua dengan Minat Belajar Siswa SMP pada Pembelajaran dari Rumah di RW II Kelurahan Parak Gadang Timur Kota Padang. Jurnal Pendidikan Tambusai, 5(1), 333-341.

Nasution. (2014). Berbagai Pendekatan dalam Proses Belajar \& Mengajar. Jakarta: Bumi Aksara.

Nopaldi, A., \& Setiawati, S. (2018). Hubungan antara Motivasi Belajar dengan Minat Belajar Warga Binaan pada Keterampilan Menjahit di Panti Sosial Karya Wanita Andam Dewi Solok. Spektrum: Jurnal Pendidikan Luar Sekolah (PLS), 1(4), 398. https://doi.org/10.24036/spektrumpls.v1i4.101463

Padalingan, R. (2016). Manfaat Bimbingan Orang Tua Terhadap Peningkatan Prestasi Belajar Peserta Didik MI No. 25 Lamasi Pantai Kecamatan Walenrang Timur Kabupaten Luwu. 1(July), 1-23.

Priyono. (2016). Metode Penelitian Kuantitatif. Sidoarjo: Zifatama Publishing.

Sesti, J. \& S. (2018). Gambaran Motivasi Warga Belajar Mengikuti Pelatihan Menjahit di PKBM Nurul Hidayah Kecamatan Kamang Magek Kabupaten Agam. Spektrum: Jurnal Pendidikan Luar Sekolah, 4(1), 449-455.

Shaumi, A. M., \& Ismaniar, I. (2020). The Relationship Between the Family Communication and Talking Early Children at the Pisang Village Kinali Districts Pasaman Barat. SPEKTRUM:

Jurnal Pendidikan Luar Sekolah (PLS), 8(4), 515.

https://doi.org/10.24036/spektrumpls.v8i4.110145

Slameto. (2003). Belajar dan Faktor-Faktor yang Mempengaruhinya. Jakarta: Rineka Cipta.

Soemanto, W. (2016). Psikologi Pendidikan. Jakarta: Rineka Cipta.

Sudjana, D. (2015). Pendidikan Luar Sekolah: Falsafah, Dasar Teori, Pendukung Azaz. Bandung: Fallah Production.

Sugiyono. (2018). Metode Pendekatan Kuantitatif. Bandung.

Suharyani. (2016). Peran Taman Pendidikan Alquran (TPQ) dalam Mengembangkan Kemampuan Membaca Alquran Bagi Peserta Didik. Jurnal Paedagogy, 3(2).

Walgito, B. (2014). Pengantar Psikologi Umum. Yogyakarta: Penerbit Andi.

Wenisa, K., \& Syuraini, S. (2020). Hubungan Perhatian Orang Tua dengan Motivasi Belajar Santri Taman Pendidikan Al- Qur' an. Jurnal Pendidikan Tambusai, 4, 2921-2926. 
Utari Handayani, Wirdatul 'Aini

Yulidar, Syuraini, \& Ismaniar. (2018). Gambaran Minat Warga Belajar Mengikuti Kegiatan Randai di Sanggar Seni Mustika Minang Duo Kota Pariaman. SPEKTRUM: Jurnal Pendidikan Luar Sekolah (PLS), 1(2). https://doi.org/10.24036/spektrumpls.v1i2.9489 